\title{
O PRIMO BASÍLIO, DE EÇA DE QUEIRÓS, E A REPRESENTAÇÃO DA MULHER (NÃO) LEITORA
}

\author{
El Primo Basilo, de Eça de Queirós, y la representación de la mujer (no) lectora
}

Eduardo Soczek Mendes ${ }^{1}$ Noeli Chemeres ${ }^{1}$

Recibido 02/12/2019

Aceptado 03/02/2020

\section{RESUMO}

O Primo Basílio, romance publicado em 1878, é uma das obras mais eminentes do escritor português José Maria Eça de Queirós (1845-1900). O romance trata, em linhas gerais, da relação extraconjugal entre as personagens de Luísa com o seu primo Basílio, tendo sido uma obra recebida com bastante polêmica na época de sua publicação. Neste trabalho, analisaremos o papel da leitura na formação da mulher como sujeito social no romance. Examinaremos, a partir de trechos, o percurso das principais personagens femininas da obra: Luísa, Juliana, Leopoldina, D. Felicidade e Joana, e o lugar da leitura em seus destinos, em um meio social patriarcal. Para a nossa fundamentação teórica, discutiremos, sobretudo, com os estudos de Fernando Catroga (1986), Marcio Jean Fialho Sousa (2015), Marisa Lajolo (1997) e Paulo Franchetti (2007).

Palavras-chave: O Primo Basílio - Eça de Queirós- Mulher - Leitura.

\section{RESUMEN}

El Primo Basilio, novela publicada en 1878, es una de las obras más eminentes del escritor portugués José María Eça de Queirós (1845-1900). La novela aborda, de manera general, la relación extra conyugal entre los personajes Luísa y su primo, Basilio. Por eso, fue recibida con mucha polémica en su período de publicación. En este trabajo de investigación, analizaremos el papel de la lectura en la formación de la mujer como sujeto social en la novela. Examinaremos, por medio de extractos de la obra, el itinerario de los principales personajes femeninos: Luísa, Juliana, Leopoldina, Doña Felicidade y Joana, y el lugar de la lectura en sus destinos, en un medio social patriarcal. Para nuestra fundamentación teórica, discutiremos con los estudios de Fernando Catroga (1986), Marcio Jean Fialho Sousa (2015), Marisa Lajolo (1997) y Paulo Franchetti (2007).

Palabras claves: El Primo Basilio - Eça de Queirós - Mujer - Lectura.

\begin{abstract}
O Primo Basilio, a novel published in 1878, is one of the most eminent works of the Portuguese writer José María Eça de Queirós (1845-1900). The novel generally deals with the extramarital relationship between the characters Luísa and her cousin, Basilio. For this reason, it was received with much controversy during its publication period. In this research, we analyze the role of reading in the formation of women as a social subject in the novel. We examine, through extracts from the work, the itinerary of the main female characters: Luísa, Juliana, Leopoldina, Doña Felicidade and Joana, and the place of reading in their destinies, in a patriarchal social environment. For our theoretical foundation, we discuss with the studies of Fernando Catroga (1986), Marcio Jean Fialho Sousa (2015), Marisa Lajolo (1997) and Paulo Franchetti (2007).
\end{abstract}

Key words: El Primo Basilio - Eça de Queirós - Woman - Reading.

\section{Introdução}

O Primo Basílio é uma das obras mais célebres de José Maria Eça de Queirós (18451900). O escritor já gozava de certo reconhecimento, por seu outro romance, O Crime do

\footnotetext{
${ }^{1}$ Universidade Estadual do Centro-Oeste (Guarapuava, Paraná, Brasil), edu.soczek@ gmail.com 
Padre Amaro $^{2}$, mas O Primo Basílio contribuiu mais decisivamente para notabilizá-lo na cena literária lusófona. A primeira edição foi lançada em 28 de fevereiro de 1878, e esgotouse rapidamente. A crítica ao romance, por sua vez, foi bastante controvertida. Houve reações favoráveis, como as de Teófilo Braga (1843-1924), que elogiavam a obra e colocavam-na à altura dos grandes romances europeus. Mas, como observa Paulo Franchetti (2007), “[...] contam-se nos dedos as apreciações positivas que recebeu" (p. 142). A recepção crítica negativa se destacou por muito tempo e o principal motivo de repreensão ao romance era a alegada imoralidade da trama e do texto, já que a temática principal da obra é o adultério.

Em meio a essas diferenças na recepção do romance, devemos entender a perspectiva do próprio autor: em grande medida, Eça estava comprometido com a causa Liberal ${ }^{3}$, que visava revolucionar a sociedade e a cultura portuguesas, destruindo as instituições que, segundo os Liberais, mantinham Portugal atrasado e impediam o seu desenvolvimento. $\mathrm{O}$ escritor lusitano considerava que a literatura deveria participar dessa mudança social, e um de seus papéis mais importantes seria o de criticar a corrupção da sociedade portuguesa, retratando de modo objetivo a realidade e buscando temáticas quotidianas. Isto é, segundo Franchetti (2007) "À literatura, assim, ficava reservado um estatuto eminentemente crítico e participativo, e por isso o seu método deveria ser a observação e a análise do tecido social contemporâneo e a sua finalidade a correção dos problemas detectados" (p. 138).

Sob esse viés, a literatura constitui uma forma de conhecimento e é socialmente engajada, uma vez que almeja contribuir para uma reforma social. O Primo Basílio, por exemplo, trata, em sua temática principal, do adultério, detalhando o caso de Luísa com o seu primo. O autor constrói, dessa maneira, a narrativa e as suas personagens a fim de denunciar a corrupção do casamento e da burguesia portugueses, nos quais o adultério era algo frequente, ainda que hipocritamente encoberto.

Como escritor Realista/Naturalista, Eça descreve de maneira rigorosa e pormenorizada a realidade social, além de imprimir detalhes que o autor pode não compreender completamente, mas que estarão na obra, como o caso da dominação patriarcal. É muito possível que Eça não estivesse comprometido em criticar o patriarcalismo da sociedade lusitana oitocentista, mas o assunto está representado em $O$ Primo Basílio: é desvelada ao leitor uma sociedade em que a mulher está subordinada, em grande medida, ao homem, o qual é o responsável pelo sustento da casa e pelas grandes decisões. Segundo Lilian Sarat de Oliveira (2008):

Desde menina [a mulher] era ensinada a ser mãe e esposa, sua educação limitavase a aprender a cozinhar, bordar, costurar, tarefas estritamente domésticas. Carregava o estigma da fragilidade, da pouca inteligência, entre outros que fundamentava a lógica patriarcal de mantê-la afastada dos espaços públicos. A negação de outros espaços além da casa/quintal as afastava também da educação formal, não sendo permitido o acesso à escola (p. 1)

\footnotetext{
${ }^{2}$ O Crime do Padre Amaro foi inicialmente publicado pela Revista Oriental, em 1875. A edição de 1875 contava com 136 páginas, enquanto que, a de 1876, possuía já 362 páginas e, a de 1880, avultava em 674 páginas. São, portanto, três obras praticamente distintas pelo adensamento e pelos retoques do autor (Mónica, 2001).

3 Após seis anos de conflitos, em 1834, os Liberais, comandados por D. Pedro IV, de Portugal, I, do Brasil (1798-1834), venceram uma Guerra Civil contra os Absolutistas, que representavam o Antigo Regime e lutavam por D. Miguel (1806-1866), irmão de Pedro. Após 1834, instaurou-se um período de mudanças na sociedade portuguesa, como a instituição da Constituição e do Parlamento, por exemplo, já reivindicados desde 1820, durante as Revoltas Liberais Vintistas. Sobre isso, é possível se aprofundar por meio do texto de Isabel Nobre Vargues e Luís Reis Torgal (1993). Vale ressaltar, porém, que o período de Eça de Queirós é o da consolidação das mudanças Liberais e da contínua proposta de renovação/modernização da sociedade portuguesa.
} 
Como podemos averiguar, as liberdades sociais da mulher eram bastante limitadas. Neste trabalho, investigaremos, mais exatamente, o papel da leitura na formação da mulher como sujeito social, uma vez que a leitura se mostra um elemento de grande relevância na trama de $O$ Primo Basílio. Para isso, propomo-nos a: contextualizar a situação da mulher na sociedade portuguesa do século XIX; examinar as personagens femininas na obra: Luísa, Juliana, Leopoldina, D. Felicidade e Joana, a condição de cada uma, a formação (ou nãoformação) dessas mulheres como leitoras e as consequências disso em suas vidas dentro da trama. Por isso, o trabalho será dividido, em seu desenvolvimento, nos seguintes tópicos: "O contexto da mulher oitocentista", "Personagens femininas" da obra e "A leitura em $O$ Primo Basílio".

Embasaremos as nossas averiguações nas propostas de Catroga (1986), Degobi (2015) e Franchetti (2007), bem como nos estudos de Lajolo (1997), Mónica (2001), Sousa (2015), Simões (1986) e Watt (2010), buscando uma aproximação do que nos propomos analisar com o contexto em que a obra veio a lume.

\section{O contexto da mulher no Portugal oitocentista}

A sociedade portuguesa oitocentista era patriarcal, pois o homem detinha diversos privilégios em detrimento das mulheres. Isso se refletia na própria Constituição Lusitana. Uma mudança modernizadora importante no Portugal oitocentista, como aponta Catroga (1986), foi a laicização do casamento, pois adequava a Constituição do país a uma sociedade Liberal. Todavia, essa mudança com o Código Civil não mudou significativamente a condição social da mulher:

[...] o casamento civil, em vez de destruir a família, pretendia protegê-la através da criação de um quadro jurídico coerente com os pressupostos jusnaturalistas e capaz de englobar a totalidade dos cidadãos. Mas, como consequência da sobre determinação masculina, a universalidade do sujeito de direito sofria uma amputação social ao dar-se à mulher um estatuto de inferioridade. Para isso, dava guarida à tradição patriarcal, integrando-a, porém, num corpus que reforçava a estrutura da família nuclear, unificada e hierarquizada a partir do poder marital, e definindo-a como a célula económica e afectiva básica para a reprodução fisiológica e social e para a interiorização ideológica dos mecanismos de autoridade. O que, em contrapartida, para além dos filhos, implicava a subalternização da mulher, status que o artigo $1185^{\circ}$ explicitamente preceituava ao mandá-la "prestar obediência ao marido" (p. 136-137)

O próprio Código Civil, como podemos observar, sendo fruto de seu período histórico, refletia a desigualdade vigente entre os homens e as mulheres na sociedade. A lei mantinha as mulheres afastadas da vida pública e das atividades políticas e econômicas. Elas precisavam, por exemplo, da autorização do marido para trabalhar no comércio e em outros negócios, ou mesmo de publicar textos. No caso de a mulher matar o esposo ou a amante do marido, em caso de adultério flagrado, ela era punida muito mais severamente do que no caso inverso (Catroga, 1986). O marido tinha poder sobre o patrimônio da esposa, determinava o destino de seus filhos, e podia até mandar a esposa para um convento. O homem tinha proeminência sobre a mulher. Conforme Simões (1986), ao homem ainda competia, em relação à mulher, "[...] exigir-lhe obediência total à sua vontade (exceto no que for ilícito ou desonesto), castigá-la ou corporalmente, desde que não empregue armas, ou fazendo-a entrar num convento, etc., etc.” (p. 173). 
É este o contexto social em que se desenrola a narrativa de O Primo Basílio: o homem detém o poder, enquanto que à mulher fica reservada a subalternidade. Subalterno é, conforme Souza (2015), aquele que

[...] não pertence a um grupo social, seu lugar não se define por padrões, são heterogêneos porque não se organizam entre si. Sendo assim, não pertencem a um grupo privilegiado (aqueles que possuem padrões), não se adequam, não possuem representatividade, são aqueles sujeitos cujas vozes não podem ser ouvidas (p. 130)

A nosso ver, as mulheres são subalternas no romance de Eça, e isso independente da classe social em que estão inseridas, embora algumas sejam ainda mais, no caso das empregadas. As mulheres vivem numa sociedade dominada por homens, os quais detêm diversos privilégios sobre elas, ou seja, mesmo que as que se rebelam ou tentam não seguir o que lhes é imposto, sofrem gravemente na sociedade.

\section{A leitura em $O$ Primo Basílio}

A leitura é um elemento central na organização do romance, e é, como afirma Lajolo (1997), a "[...] peça fundamental na caracterização das personagens" (p. 441). Não apenas Luísa, mas as demais personagens têm seus hábitos literários descritos de maneira detalhada na obra de Eça, e é visível como a prática literária de cada personagem corresponde à sua conduta e personalidade. Por exemplo, Jorge, ao invés de ler escritores românticos como Alfred de Musset (1810-1857) e Alexandre Dumas, Filho, (1824-1895), preferia autores como o cientista Louis Figuier (1819-1894), o economista e jornalista Claude Fréderic Bastiat (1801-1850), e o escritor António Feliciano de Castilho (1800-1875) (Queirós, 1982), o qual, apesar de ser incluído entre os românticos portugueses, tinha uma forte influência classicista. As obras de que cada personagem gosta refletem seu próprio caráter. No caso de Jorge, por exemplo, ele preferia, autores sóbrios, influenciados pela área científica, sem o sentimentalismo notório do Romantismo, o que parece razoável para a caracterização de um engenheiro "[...] que nunca fora sentimental" (Queirós, 1982, p. 8), além de que, como burguês, era um hábito comum a leitura de autores daquele período. Ainda a título de exemplificação, podemos mencionar a personagem do Conselheiro Acácio, que é caracterizado como um homem muito tradicional, culto, polido e mantém, em sua casa, uma biblioteca com enciclopédias, dicionários e livros de História, porque ele mesmo estava trabalhando "[...] seu novo livro - Descrições das Principais Cidades do Reino e Seus Estabelecimentos" (Queirós, 1982, p. 229), mas mantinha em sua mesa de cabeceira do

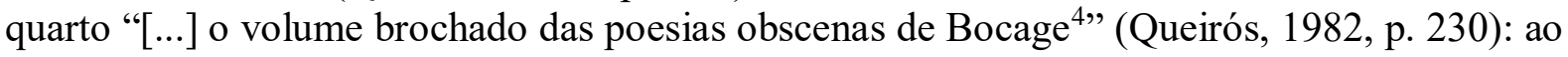
acrescentar essas informações, o narrador desvela a hipocrisia do Conselheiro, que se apresenta socialmente como um cidadão ilibado, mantendo, em seu quarto, as imagens sacras como as "[...] litografias aos lados da cama - um Ecce Homo! e a Virgem das Sete Dores" (Queirós, 1982, p. 230), contudo lê, o que para época, seria associado ao pornográfico. Após esse preâmbulo, passemos, pois, aos hábitos literários de Luísa. Lajolo (1997) discorre que:

A força da leitura na composição da personagem é tal que somos informados, logo no começo da obra que Luísa lia muitos romances e tinha uma assinatura na

\footnotetext{
${ }^{4}$ Manuel Maria Barbosa l'Hedois du Bocage (1765-1805) foi um poeta português com vasta produção lírica e satírica. Sua obra é muito diversificada, a ponto de existirem poemas de estética árcade e poemas, mantendo uma estrutura rígida, mas com temáticas eróticas e satíricas. Muitas vezes foi associado à pornografia e à imoralidade.
} 
Baixa, ao mês. E mais: o narrador mapeia, através de mudanças nas preferências literárias de Luísa, alterações em seus valores e comportamentos (p. 441)

Uma questão surge então: por que os homens da obra não leem livros românticos? A leitura de livros românticos e sentimentalistas, na obra, é algo confinado às mulheres. Primeiramente, o ponto de vista de Eça sobre as mulheres, no campo literário mais especificamente, se faz importante aí. Para ele, segundo Mónica (2001), “[...] a mulher podia ser, e era até conveniente que fosse, banal" (p. 185). Mas isso não quer dizer que todas as mulheres de suas obras sejam ingênuas, ou que a leitura dos românticos seja limitada ao público feminino. Exemplo disso é a novela $A$ tragédia da rua das flores, em que, conforme Mónica, a personagem Vítor, um rapaz de 23 anos, é leitor assíduo de autores românticos e é ingênuo. Mais do que ser mero reflexo de possíveis preconceitos do autor, em $O$ Primo Basílio o fato de a leitura dos românticos ser exclusividade de mulheres reflete a desigualdade na educação dentro do contexto social lusitano da época. Às mulheres cabia apenas uma administração parcial dos assuntos domésticos, sendo alienadas das questões que iam além do ambiente doméstico, e isso envolvia o conhecimento científico. Não havia porquê, no entender da sociedade oitocentista, de as mulheres serem instruídas com conhecimentos científicos, sendo que o papel esperado delas era atuar no lar apenas. Aos homens, por outro lado, cabiam grandes responsabilidades, e se esperava seriedade.

Há, como dito, uma profunda intertextualidade entre as personagens e as obras literárias que lêem. O gosto literário da personagem e seu caráter estão intimamente ligados, sem necessariamente haver uma relação simples de causa e efeito, isto é, a personagem não é de tal forma por ler tais obras, nem o inverso. Passaremos agora à análise mais pormenorizada das principais personagens femininas de $O$ Primo Basílio.

\section{Personagens femininas em $O$ Primo Basílio}

A protagonista do romance, Luísa, é uma mulher burguesa, dona de casa, casada com Jorge, um engenheiro. Ela e o marido viviam harmoniosamente, sem filhos. Seu tempo era ocupado com os assuntos domésticos, com a leitura, assim como eventuais visitas, que não eram frequentes, mas ao menos nas noites de domingo a casa era visitada pelo círculo restrito de amigos, como o conselheiro Acácio e Sebastião, íntimo amigo de Jorge. Às vezes, Luísa se encontrava com sua amiga Leopoldina.

Luísa era considerada uma esposa exemplar: era dedicada ao marido e à casa, parecia uma mulher ingênua e casta, isto é, era uma mulher que se adequava harmonicamente ao papel social a ela reservado.

Na primeira parte do romance, Jorge viaja a negócios. É quando o primo Basílio, de Luísa, que foi seu namorado na juventude, regressa a Lisboa e começa a fazer visitas a ela. A pessoa de Basílio mexe com Luísa, fazendo-a reavivar os sentimentos provenientes da experiência que tiveram no passado. O narrador afirma que "[...] durante todo o dia, Luísa em roupão não saiu do seu quarto ou da sala, ora estendida na causeuse lendo aos bocados, ora batendo distraidamente no piano pedaços de valsas" (Queirós, 1982, p. 61). A leitura era uma distração importante a ela, pois fora isso, não tinha muito com o que se entreter e ocupar o seu tempo, fugindo da monotonia. Nas palavras de Mónica (2001): "Sozinha, Luísa aborrecese. Sem filhos, nada tem que a ocupe. Lisboa está alquebrada pelo calor" (p. 176). O próprio clima contribui para a monotonia.

Um romance sobre o qual Basílio comenta com Luísa é a obra francesa Mulher de Fogo, de Adolphe Belot (1829-1890), publicado em 1872. Ele diz que é picante, e por isso não lhe recomenda, já que não sendo conveniente a uma mulher casada. Mas isso constitui uma indireta de Basílio para provocar Luísa com o assunto do livro. Percebemos aí o 
paralelismo entre a trama e as obras lidas e citadas pelas personagens: o romance de Belot, picante e não aconselhável às mulheres recatadas, corresponde às experiências de mesmo tipo que Basílio quer ter com Luísa, e que acabam tendo (Queirós, 1982).

Basílio, enquanto contava a Luísa sobre a literatura amorosa moderna, falava de tal modo sobre o adultério que demonstrava o ato como algo positivo. "O adultério aparecia assim um dever aristocrático. De resto a virtude parecia ser, pelo que ele contava, o defeito dum espírito pequeno, ou a ocupação reles dum temperamento burguês..." (Queirós, 1982, p. 90). Percebemos aí um jogo com as classes: a aristocracia é uma classe associada ao passado e ao mundo imaginário, enquanto que a burguesia é vinculada ao momento vivido na trama. Basílio associa, assim, o adultério ao passado e à classe que tantas vezes fora retratada pelo Romantismo, sobretudo em romances históricos, pintando-a com cores bonitas a fim de convencer Luísa.

Além de Basílio, outra pessoa influente sobre ela é Leopoldina, sua amiga, casada, mas notória por suas aventuras amorosas extraconjugais, as quais ela conta a Luísa.

Dessa maneira, Luísa esperava viver as belas experiências dos romances que lia:

Em solteira, aos dezoito anos, entusiasmara-se por Walter $\operatorname{Scott}^{5}$ e pela Escócia; desejara então viver num daqueles castelos escoceses, que têm sobre as ogivas os brasões do clã; mobilados com arcas góticas e troféus de armas, forrados de largas tapeçarias [...]; e amara Ervandalo, Morton e Ivanhoé, ternos e graves, tendo sobre o gorro a pena da águia, presa ao lado pelo cardo de Escócia de esmeraldas e diamantes. Mas agora era o moderno que a cativava, Paris, as suas mobílias, as suas sentimentalidades. Ria-se dos trovadores, exaltara-se por Mr. De Camors; e os homens ideais apareciam-lhe de gravata branca, nas ombreiras das salas de baile, com seu magnetismo no olhar, devorados de paixão, tendo palavras sublimes. Havia uma semana que se interessava por Marguerite Gautier: o seu amor infeliz dava-lhe uma melancolia enevoada; via-se alta e magra, com o seu longo xale de caxemira, os olhos negros cheios de avidez da paixão e dos ardores da tísica; nos nomes mesmo do livro - Julie Duprat, Armand, Prudence, achava o sabor poético duma vida intensamente amorosa [...] (Queirós, 1982, p. 11-12).

Percebemos como as mudanças nas leituras de Luísa refletem mudanças de valores e de comportamento, como sugere Lajolo. Na juventude, fantasiava viver em um castelo, na Escócia, com algum dos heróis dos romances que lia. Vale ressaltar que Eça, talvez, esteja, por meio da elaboração de seu romance, tecendo uma crítica ao Medievalismo e Historicismo do Romantismo Nacionalista, que trazia a idealização da sociedade medieval e a construção de ambientes pretéritos: podemos inferir, por meio do relato da voz narrativa, que há uma insinuação de que os romances históricos contribuíam para a alienação social, sobretudo das mulheres. No momento da narrativa, contudo, os gostos de Luísa mudaram: agora sonha com a fineza e elegância de Paris. Quem sabe Basílio não poderia satisfazer essas suas fantasias.

Luísa se mostra bastante influenciável, e Basílio se aproveita disso para enganá-la. Talvez, também a voz narrativa do romance, guardadas as proporções do período histórico e de suas próprias concepções temporais, estivesse relatando, de forma latente, um preconceito: o de como as mulheres são ingênuas e facilmente manipuláveis. Basílio, por exemplo, apenas estava usando Luísa e alimentava as fantasias dela, inspiradas pelos romances, com sugestões

\footnotetext{
5 Walter Scott (1771-1832), nascido na Escócia, é considerado o pai do romance histórico tradicional. Waverley(1814) e Ivanhoé(1819) foram as suas obras romanescas mais eminentes e geraram, juntamente com as produções do escritor francês Victor Hugo (1802-1885), uma grande tradição de produção de romances históricos, inclusive em Portugal (Marinho, 1999). Almeida Garrett (1799-1854), Alexandre Herculano (18101877) e Camilo Castelo Branco (1825-1890) são exemplos de autores portugueses tributários de Scott e Hugo.
} 
de um amor intenso, que ele não tinha, como em um de seus bilhetes à prima: “[...] tu és o único laço que me prende à vida, e se amanha perdesse o teu amor, juro-te que punha um termo, com uma boa bala, a esta existência inútil!" (Queirós, 1982, p. 125). Mas as suas intenções eram egoístas: "[...] usava dela, como se a pagasse", comparando-a a uma prostituta (Queirós, 1982, p. 148).

Luísa muda visivelmente quando passa a ter seu caso com Basílio. Sebastião, amigo íntimo de Jorge, percebe isso. Ela não tinha mais a brandura e aparente ingenuidade de antes. "Parecia-lhe aquela uma outra Luísa, diferente, que o assustava; e quase curvava os ombros sob a estridência da sua voz, que nunca conhecera tão forte, vibrando numa loquacidade trapalhona" (Queirós, 1982, p. 110). A personagem estava muito bem de humor, por ter um amante. Sentia-se mais bonita, lembrando-se do que Leopoldina disse a ela: "[...] não havia como uma maldadezinha para fazer a gente bonita" (Queirós, 1982, p. 126). Luísa queria ser rica, ter coisas finas, e se torna arrogante, como seu amante, se influenciando por suas ideias, "[...] até afetar, sem o sentir, um desdém pela gente virtuosa, para imitar as suas opiniões libertinas" (Queirós, 1982, p. 148).

Basílio aluga um quarto em uma região afastada de Lisboa para se encontrar com a amante, lugar este que ele chama de Paraíso. Luísa fica entusiasmada, imaginando mais uma vez que vai viver as aventuras que leu em romances: "[...] aquele Paraíso secreto, como num romance, lhe dava a esperança de felicidades excepcionais" (Queirós, 1982, p. 132). Ela projeta para o Paraíso suas expectativas: "Ia, enfim, ter ela própria aquela aventura que lera tantas vezes nos romances amorosos! Era uma forma nova do amor que ia experimentar, sensações excepcionais! Havia tudo - a casinha misteriosa, o segredo ilegítimo, todas as palpitações do perigo!" (Queirós, 1982, p. 136). Ela lera um romance de Paul Féval (18161887), no qual o herói encontra sua amante numa choça. Luísa criava altas expectativas, esperando uma aventura repleta de prazeres e luxo. "Desejava chegar num coupéseu, com rendas de centos de mil-réis, e ditos tão espirituosos como um livro..." (Queirós, 1982, p. 136). Mas, quando ela vai pela primeira vez ao dito Paraíso, fica decepcionada, vendo que se trata de um quarto pobre, em más condições, no subúrbio da cidade: "Luísa viu logo, ao fundo, uma cama de ferro com uma colcha amarelada, feita de remendos juntos de chitas diferentes; e os lençóis grossos, dum branco encardido e mal lavado, estavam impudicamente entreabertos..." (Queirós, 1982, p. 137). Ela fica muito decepcionada:

Assim um iate que aparelhou nobremente para uma viagem romanesca vai encalhar, ao partir, nos lodaçais do rio baixo; e o mestre aventureiro, que sonhava com os incensos e os almíscares das florestas aromáticas, imóvel sobre o seu tombadilho, tapa o nariz aos cheiros dos esgotos (Queirós, 1982, p. 138)

O narrador retrata aí, de maneira figurada, o contraste entre as altas expectativas românticas de Luísa e a reles realidade que Basílio lhe oferece. Ela esperava algo tão fino e luxuoso, mas Basílio arranja um quarto sujo, abaixo de sua condição social. Aí também deslumbramos de forma mais clara uma característica da corrente literária de Eça: o Realismo. Ou seja, a preferência pela "verdade humana" exige que o escritor busque retratar a vida como ela é, em vez de idealizá-la, o que resulta em contrastes do tipo apontado no trecho de $O$ Primo Basílio: Luísa esperava algo bonito e luxuoso, mas, como a vida não é "só flores", teve o contrário. Percebemos também como o narrador faz repetidas referências às leituras de Luísa, contrastando a sua realidade com as obras que moldaram suas ideias.

Com o tempo, Basílio muda o seu jeito de tratar Luísa: antes era atencioso, mas passa a ter modos ríspidos e fala com ar de superioridade. Ela começava a duvidar das vantagens de sua aventura amorosa: "E já pensava um pouco que sacrificara a sua tranquilidade tão feliz a um amor bem incerto" (Queirós, 1982, p. 154). Mesmo nessas circunstâncias, a tendência de 
Luísa a idealizar, alimentada pelas leituras, continua agindo: lembrando-se do marido, pensa que, para ele, "[...] ela era decerto a mais linda, a mais elegante, a mais inteligente, a mais cativante!" (Queirós, 1982, p. 154).

Luísa percebeu, então, que não era o amor que movia Basílio e ela. No caso dela, nem ela mesma sabia: "[...] não ter nada que fazer, a curiosidade romanesca e mórbida de ter um amante, mil vaidade zinhas inflamadas, um certo desejo físico" (Queirós, 1982, p. 156). Ela percebia a lógica do adultério. É um "amor" muito frágil, "[...] na hora em que nasce começa a morrer. Só os começos são bons" (Queirós, 1982, p. 157). Por isso, pensava ela, Leopoldina era tão inconstante nas aventuras amorosas e vivia trocando de amante: por conta da inconstância da paixão.

A princípio, Luísa se dava desculpas para seu adultério. "Tinha sido uma fatalidade: fora o calor da hora, o crepúsculo, uma pontinha de vinho talvez" (Queirós, 1982, p. 127). Mas, depois, passa a sofrer às vezes em sua consciência. Em sua mente vinha a imagem de Jorge como um marido dedicado e amoroso. Um dos maiores críticos que O Primo Basílio teve foi Machado de Assis ${ }^{6}$, o qual acusava a obra, como tantos outros críticos, de imoralidade, e, como mostram Mónica (2001) e Franchetti (2007), para ele Luísa era uma personagem plana e incompleta, não tendo muito mais que carne e osso, pois ela não tinha remorso. Mas isso não é verdade. Há passagens que indicam como ela sofria em sua consciência, como quando se lembra da época em que estava encamada de pneumonia e Jorge cuidava dela com tanto zelo (Queirós, 1982), ou quando pegou a foto do marido e a beijou, em lágrimas, pedindo para ele perdoá-la (Queirós, 1982). Não se trata de ela não sentir remorso pela traição cometida. Acontece que isso é desvelado sucintamente no romance.

Entretanto, concordamos com Machado de Assis no seguinte aspecto: na primeira metade do romance, o "cordel que move a alma inerte" de Luísa está nas mãos de Basílio, enquanto que na segunda metade passa para as mãos de Juliana (como citado em Franchetti, 2007).

Juliana, empregada de Luísa, toma secretamente umas cartas de Luísa para Basílio. Como consta no fim do capítulo VII, num dado dia, Luísa estava muito irritada por não se encontrar com o amante, e trata muito mal Juliana. A empregada se revolta e expõe sua arma contra Luísa, a posse das cartas. Foi por conta do temperamento instável e caprichoso de Luísa que Juliana se revolta abertamente contra ela. No capítulo VIII, Luísa tenta resolver o problema com a ajuda de Basílio. Ela propõe ao primo que eles fujam, como os romances, mas ele se acovarda. Basílio foge sozinho. Eles nunca mais se veriam. "Ele partia alegre, levando as recordações romanescas da aventura; ela ficava, nas amarguras permanentes do erro. E assim era o mundo!" (Queirós, 1982, p. 186-187).

Um detalhe muito importante, que não deve passar despercebido, é que Jorge também traía Luísa. É o que ele próprio assume em carta a Sebastião, no capítulo VIII. Ele fala de seu sucesso com várias mulheres na cidade onde estava de viagem. Luísa fica furiosa quanto lê essa carta, a contragosto de Sebastião. Este capítulo marca o ápice da reviravolta da história: Luísa já tinha cometido o adultério, Basílio fugira, ela estava nas mãos de Juliana; até então se consolava com a lembrança da confiança do marido, fiel e amoroso, que sempre a apoiou; mas aí ela descobre que ele próprio a traía.

Juliana chantageia Luísa, exigindo cada vez mais coisas. Em meio à sua desgraça, Luísa tinha de vez em quando vontade de se meter num convento, destino usual para mulheres rebeldes da época. Ela se lembrava então das leituras do escritor britânico Walter Scott, e pensava em como sua vida seria diferente se tivesse seguido a vida religiosa. Poderia

\footnotetext{
${ }^{6}$ Machado de Assis (1839-1908), escritor brasileiro, publicou, em 1878, no periódico O Cruzeiro dois artigos criticando Eça de Queirós (Mónica, 2001), sobretudo pelos romances $O$ crime do Padre Amaro e $O$ primo Basílio.
} 
estar em algum mosteiro escocês remoto (Queirós, 1982). Vemos aí novamente as fantasias de Luísa baseadas em suas leituras românticas. Ela queria fugir da realidade. Acreditava que, como freira, seu destino teria sido melhor. Esse trecho pode também ser entendido como mais uma crítica de Eça aos Românticos: eles idealizavam o passado de maneira a oferecer uma reconstrução que nem sempre tinha a ver com a realidade histórica, o que poderia resultar na desinformação de leitores ingênuos, como é o caso de Luísa.

Ela tinha, às vezes, repentinamente, febres efêmeras, emagrecia e tinha ataques de melancolia. A vizinhança já sabia que ela "ia mal". Para o Paula, o comerciante, Luísa estava mal porque lia demais: "Ali anda coisa de cabeça [...]. Sabe o que ela tem, Sra. Helena? É muita dose de novelas naquela cachimônia. Eu vejo-a de pela manhã até à noite de livro na mão. Põe-se a ler romances e mais romances... Aí têm o resultado: arrasada!" (Queirós, 1982, p. 240). Vemos nisso o imaginário das pessoas sobre a leitura para as mulheres.

Luísa mostra ser uma leitora ingênua, com problema para diferenciar a ficção da realidade. A leitura funciona como uma válvula de escape, para ela fugir da realidade, ora da monotonia, no começo, ora do sofrimento causado pela extorsão de Juliana.

Juliana é uma das principais personagens femininas da obra. Era a empregada interna da casa de Jorge e Luísa. Ela era bastante ressentida, em parte por conta de sua vida sofrida de empregada. Sempre à espreita para escutar alguma fofoca. Com um segredo comprometedor, ela poderia chantagear sua patroa, conforme o autor deixa claro: "Andava à busca de um segredo, de um bom segredo! Se lhe caía um nas mãos!" (Queirós, 1982, p. 54). Deve-se acrescentar que ela não tinha muitos contatos ou amizades.

Ela era feia e virgem, o narrador acrescenta, o que aumentava seu rancor: "Fora sempre feia, ninguém a tentara" (Queirós, 1982, p. 55). Não gozava dos prazeres que Joana, a cozinheira, tinha com as suas aventuras amorosas. O caráter rancoroso de Juliana é determinado, em parte ao menos, por fatores exteriores à vontade dela, como sua aparência física, motivo de deboche para os outros e que não lhe dá a facilidade de ter as experiências amorosas que as outras mulheres têm, o que lhe suscita inveja. Os pés eram o que mais lhe dava orgulho. Eram pequenos e bonitos. Ela tinha bastante satisfação em gastar com botas para os pés: "O pé era o seu orgulho, a sua mania, a sua despesa. Tinha-o bonito e pequenino" (Queirós, 1982, p. 57).

Juliana se sentia superior à outra empregada da casa por ser a criada interna, tendo contato com as visitas e servindo diretamente aos patrões, enquanto Joana, a outra criada, era a cozinheira. Na cena em que Juliana vai ao quarto desta para conversar, notamos isso. Ela só fica, a princípio, na porta do quarto da outra: "Mas não entrou, ficou à porta; era criada de dentro, evitava familiaridades" (Queirós, 1982, p. 50). Mesmo assim, era, muitas vezes, explorada pela patroa, como é o caso do trecho que segue: "A porta do quarto rangeu devagarinho. / - Que é? / A voz de Juliana, plangente, disse: - A senhora dá licença que eu vá logo ao médico? / - Vá, mas não se demore [...] arranje tudo antes. E não se demore, hein?" (Queirós, 1982, p. 41)

Não há notícias de leituras de Juliana em O Primo Basílio. Percebemos, no entanto, que ela era alfabetizada, pois do contrário, ao pegar as cartas de Luísa e Basílio, não saberia do que se tratava.

A prática da leitura é um distintivo dos privilegiados neste contexto, pois são os privilegiados que podem ler. Juliana, por sua condição, não tem o hábito da leitura, e talvez nem tenha tempo suficiente, nem dinheiro. Seu sucesso se deve à sua astúcia e à oportunidade, que, depois de anos servindo a fio, finalmente consegue. Em posse das cartas, ela chantageia Luísa e tenta cumprir os seus planos. A falta de leitura de Juliana influencia em sua caracterização, pois, na falta da instrução proveniente da leitura, os horizontes de suas pretensões são limitados: o que ela quer é garantir seu sustento na velhice, contenta-se com presentes, móveis e roupas novas. Antes disso, sua mente se ocupava remoendo o rancor 
contra Luísa e sua vida infeliz. Juliana não tem a válvula de escape que Luísa tem, isto é, os livros.

Consideremos agora a personagem Leopoldina. Ela é uma burguesa, grande amiga de Luísa. Sua primeira aparição no romance é em uma visita que faz a Luísa, quando Jorge já tinha saído em viagem. Ela tem um casamento infeliz e é notória por suas aventuras amorosas, o que lhe dá má fama. "Jorge odiava-a. E dissera muitas vezes a Luísa: 'Tudo, menos a Leopoldina!'” (Queirós, 1982, p. 16).

Leopoldina compartilha as suas aventuras nas conversas que tem com Luísa. Em uma dessas conversas ela conta à amiga os vários casos e escândalos envolvendo mulheres casadas de Lisboa. Leopoldina as odiava, pois elas conseguiam manter uma aparência de decência em público, o que ela não conseguia, permanecendo em má fama na sociedade (Queirós, 1982, p. 247).

Por sua condição social, Leopoldina tem contato com a leitura, embora provavelmente não seja uma leitora tão assídua quanto Luísa, em parte por ela não ser reclusa ao meio doméstico, como é Luísa (ao menos até a chegada de Basílio). Um exemplo da familiaridade de Leopoldina com a leitura é a cena em que ela mostra a Luísa um poema feito por um de seu amante. Ela lê o poema para a amiga cheia de orgulho e comoção, depois do que ficam ambas caladas “[...] com uma como çãozinha” (Queirós, 1982, p. 19).

Leopoldina tinha plena ciência dos privilégios dos homens sobre as mulheres. "Os homens são bem mais felizes que nós! Eu nasci para homem! O que eu faria! [...] Um homem pode fazer tudo! Nada lhe fica mal! Pode viajar, correr aventuras..." (Queirós, 1982, p. 117). Por se comportar como homem, não é aceita.

Leopoldina não tem o mesmo fim triste de Luísa, mas ela mesma é socialmente malsucedida, porque tem má fama e é infeliz no casamento. Devemos lembrar que o casamento é extremamente importante no Romantismo. Criticar o casamento é criticar o Romantismo, e é o que Eça faz, criticar o casamento burguês lisboeta. A transgressão do casamento, como Luísa e Leopoldina fazem, é igualmente uma ruptura com os ideais românticos.

No entanto, Leopoldina tem satisfação em suas aventuras amorosas. Ela se notabiliza por transgredir o papel que se espera de uma mulher no seu contexto social, se equiparando aos homens com seus adultérios, como propõe Degobi (2015): "Devido à sua posição de mulher infiel e adúltera, Leopoldina pertencia ao espaço privado que era destinado aos homens" (p. 70).

Passemos à análise de D. Felicidade. Ela era uma mulher também burguesa, de idade avançada, solteirona. Representa, nas palavras do próprio Eça, em carta a Teófilo Braga (1843-1924), datada de março de 1878, “[...] a beatice parva de temperamento irritado" (Queirós, 1982, p. 318). Ela fazia parte do círculo íntimo de amigos de Jorge e Luísa. Portanto, o autor afirma que D. Felicidade é a personificação da crença boba/idiotice/tolice.

A única referência à leitura dela é a obra Rocambole, anti-herói de uma série de obras de Ponson Du Terrail (1829-1871). Mas era muito difícil para D. Felicidade de manter continuidade nessa leitura, e ela iria pará-la, pois "[...] aumentava a indigestão" (Queirós, 1982, p. 65). Está aí um problema que a perseguia, a indigestão. Todavia, era a indigestão que a impedia de ler, ou a incapacidade? Possivelmente a indigestão fosse apenas uma desculpa sua para sua falta de hábito de leitura. Além do mais ela é facilmente enganada.

Para D. Felicidade, a leitura seria apenas uma forma de ocupar o tempo livre, como era comum às mulheres burguesas. No entanto, ela não aparenta ser uma leitora assídua. Além disso, D. Felicidade tinha ideias muito retrógradas, segundo o conselheiro Acácio, possivelmente se referindo à religiosidade e superstições dela, o que fica bastante claro quando D. Felicidade encomenda os serviços de uma feiticeira para fazer com que o conselheiro se apaixonasse por ela (Queirós, 1982). Ela acaba ludibriada: o rapaz a quem 
confiara o dinheiro para entregar à feiticeira foge com a quantia. Passemos à verificação de duas personagens mais: Joana e Vitória Soares.

Joana é a cozinheira da casa de Luísa. Além do trabalho, ela se ocupava com seu namorado: "Joana era decerto espessa e obtusa; além disso a paixão animal pelo rapazola emparvecia-a" (Queirós, 1982, p. 150). Tem, portanto, um caráter mais simples em relação a Juliana. Não há referências às leituras de Joana no romance. Provavelmente, nem as tinha, uma vez que, além do trabalho, que lhe ocupa bastante tempo, tinha o namoro como entretenimento, ao invés de livros.

Uma personagem secundária, mas que chama a atenção é Vitória Soares, amiga de Juliana. Ela é uma inculcadeira bastante procurada. Tinha muitos contatos e fazia diversos serviços:

Emprestava dinheiro aos desempregados; guardava as economias dos poupados; fazia escrever pelo Sr. Gouveia as correspondências amorosas ou domésticas dos que não tinham ido à escola; vendia vestidos em segunda mão; alugava casacas; aconselhava colocações, recebia confidências, dirigia intrigas, entendia de partos. [...] E dizia-se: a tia Vitória tem mais manhas que cabelos! (QUEIRÓS, 1982, p. 150)

Era uma mulher bastante influente no contexto social da história, ainda que sendo uma personagem secundária. A sua formação como leitora, por sua vez, é duvidosa. Só há a referência de que ela era auxiliada por um homem, o Sr. Gouveia, para escrever as cartas de clientes (Queirós, 1982, p. 150). Talvez ela precisasse dele por ela não ser devidamente alfabetizada, ou talvez porque preferia deixar outra pessoa a cargo disso e se ocupar de outras coisas. Juliana a consultava frequentemente, para saber o que fazer quanto a Luísa. Tia Vitória instrui Juliana a como proceder para tirar vantagem das cartas (Queirós, 1982).

\section{Considerações Finais}

O presente trabalho nos faz notar como a leitura tem diferentes espaços na vida das diversas personagens na trama de $O$ Primo Basílio. Um fator de diferenciação é a classe social: as personagens da classe trabalhadora, como Juliana e Joana, dispõem de pouco tempo ocioso, além de escasso dinheiro, para se dedicarem à leitura, ao contrário das burguesas Luísa, Leopoldina e D. Felicidade. Um entretenimento alternativo é as aventuras amorosas, das quais Joana goza, mas não Juliana. A leitura é uma prática mais ao alcance da burguesia do que dos trabalhadores do povo.

Percebemos também certa diferença entre as personagens de diferentes sexos. Por um lado, as mulheres burguesas participavam da cultura livresca. Watt (2010), por exemplo, analisa em $A$ ascensão do romance o contexto social da Inglaterra setecentista, de modo que é possível, guardadas as suas proporções, estender a sua análise ao Portugal oitocentista, tendo em vista algumas similaridades dos contextos sociais. Watt se embasa, citando as propostas do escritor inglês Joseph Addison (1672-1719), publicadas no periódico Guardian, em 1713:

Há algumas razões pelas quais o estudo se adapta melhor ao mundo feminino que ao masculino. Primeiro, porque as mulheres dispõem de mais tempo livre e levam uma vida mais sedentária [...] Existe outra razão para que sobretudo as mulheres de posição se dediquem às letras, a saber, porque seus maridos geralmente não são versados nelas (Addison apud Watt, p. 46) 
Segundo a concepção de Addison, escritor no período da eclosão da publicação romanesca, os homens, burgueses inclusive, se ocupavam das mais diversas tarefas e atividades fora do lar, e, por conta dessa constante ocupação, tinham pouco tempo livre para se dedicar à leitura como mero lazer. Com as mulheres burguesas ocorria o contrário: têm muito tempo livre e são, por consequência, o foco do mercado livreiro do período, como afirma Watt (2010): "[...] dispunham de muito tempo livre e ocupavam-no basicamente devorando livros" (p. 46). Luísa, por exemplo, lia para fugir do tédio.

No Portugal oitocentista, retratado em $O$ Primo Basílio, os homens, principalmente burgueses, liam tanto quanto as mulheres. No entanto, há diferenças entre as leituras deles e as leituras delas: a leitura de romances parece reservada ao público feminino, enquanto que ao masculino ficam destinadas obras, por exemplo, de cunho científico. Para as mulheres, a leitura é um lazer, uma forma de ocupar o tempo; para os homens, apesar de poder ser um lazer, é também um auxílio em suas ocupações e trabalhos. O conhecimento técnico e científico é reservado aos homens. Por isso, a Luísa só cabia a leitura de ficção, de romances.

Um problema de Luísa é que ela confunde a ficção com a realidade. Ela quer viver as aventuras que leu. Em parte, esse erro seu pode ser atribuído a uma má instrução ou mesmo à natureza das mulheres, que resultam numa ingenuidade que a leva a agir assim, uma vez que a instrução avançada era exclusiva dos homens. Mas isso também pode ser atribuído ao Romantismo, que Eça critica: os autores Românticos idealizam a realidade, seja o passado medieval ou Paris, oferecendo ao leitor um quadro ingênuo dessa realidade, que fica distorcida, resultando na desinformação do leitor sem senso crítico, como parece ser o caso de Luísa.

Em meio aos relatos dentro do romance e a própria trama, o adultério aparece como uma prática bastante disseminada. Luísa trai o marido, Leopoldina também, e diversas outras mulheres, como Leopoldina relata; os homens também traem, incluindo Jorge, como ele confessa em carta para Sebastião (Queirós, 1982). O próprio conselheiro Acácio, personagem tão sério, erudito e de postura tão conservadora, tinha por amante sua empregada Adelaide, a qual também tinha caso com um caixeiro (Queirós, 1982). Mas o adultério era visto como algo mais natural aos homens. As punições eram mais severas para a esposa adúltera do que para o esposo adúltero. Leopoldina é uma mulher que ousa ter aventuras amorosas, mesmo com o conhecimento público. Ela ousa fazer aquilo que os homens também fazem. E por isso tem uma má reputação.

Embora o objetivo de Eça, provavelmente, não seja a realização de uma crítica à sociedade patriarcal, uma vez que ele tinha a intenção de criticar toda a sociedade burguesa lisboeta, retratando sua mediocridade e corrupção, ele acaba por fazer, conjuntamente, uma crítica à situação da mulher em tal contexto. Em nossa análise, podemos perceber que, mesmo que o narrador projete em Luísa a forma de uma iludida pela literatura Romântica, o destino das outras personagens femininas não é mais exitoso. Todas sofrem, a seu modo, com a situação social patriarcal da sociedade burguesa em que estão inseridas, modo que não é a leitura ou a não-leitura que desgraça a vida dessas mulheres, como, talvez, o próprio autor queria fazer crer.

\section{Referências Bibliográficas}

Catroga, F. (1986). A laicização do casamento e o feminismo republicano. In:V. Ferreira (org.) Actas, Vol. I.do colóquio "A mulher na sociedade portuguesa: visão histórica e perspectivas actuais". (p. 135-147) Coimbra: Instituto de História Económica e Social, Faculdade de Letras da Universidade de Coimbra.

Degobi, F. C. (2015). A Construção das Personagens Femininas na obra O Primo Basílio, de Eça de Queirós [Monografia]. Recuperado a partir de 
http://unifafibe.com.br/revistasonline/arquivos/revistaletrasfafibe/sumario/41/13092016190103. pdf

Franchetti, P. (2007). O Primo Basílio. In: P. Franchetti (org.). Estudos de Literatura Brasileira e Portuguesa (p. 135-157). São Paulo: Ateliê Editorial.

Lajolo, M. (1997). Eça de Queirós e suas leitoras mal comportadas. In: E. Miné \& B. J. Caniato (orgs.). Anais do III Encontro Internacional de Estudos Queirosianos - 150 anos com Eça de Queirós. (p. 438-445). São Paulo: Centro de Estudos Portugueses: Área de Estudos Comparados de Literaturas de Língua Portuguesa/ FFLCH/USP.

Marinho, M. de F. (1999). O romance histórico em Portugal. Porto: Campo das Letras.

Mónica, M. F. (2001). Eça: Vida e obra de José Maria Eça de Queirós. Rio de Janeiro: Record.

Oliveira, L. S. de. (2008). Educação e religião das mulheres no Brasil do século XIX: conformação e resistência [Anais de Evento]. Recuperado a partir dehttp://www.fazendogenero.ufsc.br/8/sts/ST27/Lilian_Sarat_de_Oliveira_27.pdf

Queirós, E. de. (1982). O Primo Basílio. São Paulo: Abril Cultural.

Queirós, E. de. (1982). "O Primo Basílio": Carta a Teófilo Braga. In: E. de Queirós. O Primo Basílio. (p. 317-319). São Paulo: Abril Cultural.

Simões, M. L. da C. (1986). Um divórcio no $1^{\circ}$ quartel do século XIX. In: V. Ferreira (org.) Actas, Vol. I.do colóquio "A mulher na sociedade portuguesa: visão histórica e perspectivas actuais". (p. 171-189) Coimbra: Instituto de História Económica e Social, Faculdade de Letras da Universidade de Coimbra.

Souza, M. J. F. (2015, Março). As faces da subalternidade feminina no Portugal oitocentista em $O$ Primo Basílio, de Eça de Queirós. Revista Muitas Vozes - Programa de Pós-Graduação em Linguagem, Identidade e Subjetividade - Universidade Estadual de Ponta Grossa, 4, n. 2, 129136.

Vargues, I. N. \& Torgal, L. R. (1993). Da revolução à contra-revolução: vintismo, cartismo, absolutismo. In: J. Mattoso (dir.). História de Portugal: o Liberalismo (1807-1890): Quinto Volume. Lisboa: Editora Estampa.

Watt, I. (2010). A ascensão do romance: estudos sobre Defoe, Richardson e Fielding. São Paulo: Companhia das Letras. 